VLADAN MIĆIĆ, MILOVAN JOTANOVIĆ*

University of East Sarajevo, Faculty of Technology Zvornik, Zvornik, Republic of Srpska, Bosnia and Herzegovina
Scientific paper

ISSN 0351-9465, E-ISSN 2466-2585

UDC:662.754.2:621.43

doi: $10.5937 /$ ZasMat1504403M

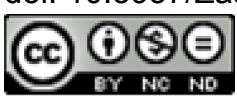

Zastita Materijala 56 (4)

403 - 408 (2015)

\title{
Bioethanol as fuel for internal combustion engines
}

\begin{abstract}
The most promising biofuels are bioethanol, biodiesel, pure plant oil, and biomethane. Many biofuels generate large benefits when compared to fossil fuels. The use of bioethanol will largely depend on the potential of available and continuously re-growing biomass, the feedstock sources. Bioethanol produced from renewable feedstock has great potential to reduce greenhouse gasses emissions related to the combustion of fossil fuels. It has chemical and physical properties that are close to fuels from fossil fuels and can be used to exchange petrol in existing engines. Generally bioethanol is expected to have large socio-economic impacts, especially for local actors. Bioethanol production opens new market opportunities for agricultural products and thus new income options for farmers. In the future agriculture will not only play a role in food production, but also in energy provision.
\end{abstract}

Keywords: biofuel, bioetanol, renewable energy sources, biomass, fossil fuels.

\section{INTRODUCTION}

Today, applications in the transport sector are based on the use of liquid fuels which are easy to store. In comparison with liquid fuels, the use of gaseous fuels for transport purposes is minor. Although solid fuels were used in the past for railway trains, they are not applied for transport uses since a long time. However, apart from the phase of matter generally two basically different types of fuels exist: fuels made from fossil resources and biofuels made from renewable resources [1-3].

In general, the use of biofuels will largely depend on the potential of available and continuously re-growing biomass, the feedstock sources. Another aspect which commonly influences all biofuels is the biofuel policy. Suitable policies on regional, national and on the EU level are one of the main determinants that can largely contribute to the success of biofuel market penetration. In the EU several targets have been set to promote biofuels. The main common characteristics of biofuels are expressed by a similar life cycle $[2,4,5]$.

The largest portion of biofuels is received from vegetable feedstock sources. They all have to be cultivated, transported and processed into the final biofuel. Wastes and animal residues can also be used as feedstock source $[6,7]$.

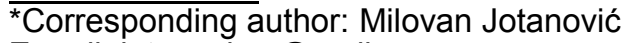

E-mail: jotanovicm@mail.ru

Paper received: 18. 03. 2015.

Paper accepted: 07. 05. 2015.

Paper is available on the website:

www.idk.org.rs/casopis
}

Bioethanol is one of the promising biofuels. Today, a much larger portion of bioethanol is traded for purposes other than transport applications. Most ethanol is traded for alcoholic beverages, for solvent purposes, and for other industrial applications. Nevertheless, fuel ethanol will be traded increasingly as crude oil prices rise and as governments adopt new policies promoting biofuels $[2,8]$.

Currently, Brazil is the main exporter for ethanol. The export of Brazilian sugar cane ethanol for all uses accounts approximately half of total global trade of liquid renewable biofuels. Several other producer countries, including Pakistan, the United States, South Africa, Ukraine, and countries in Central America and the Caribbean, also contribute to ethanol trade, though their relative exports compared to Brazil are quite small. Also small amounts of ethanol are shipped from Africa and Asia to Europe. This is mainly due to preferential access to the European market. Pakistan has historically been the largest exporter of ethanol to the European Union. Most of the ethanol traded today is preprocessed ethanol, manufactured in the country where the feedstock is grown, as it has generally not been economical to transport feedstock long distances for ethanol production. As sugar is currently the cheapest feedstock, many low-cost producers of sugar cane in Africa, Latin America, and Asia plan to increase their share in global ethanol trade. International trade depends on policies, import restrictions and import duties [8]. In order to facilitate trade between the EU and other countries, the EU exempted 
certain countries from import duty fees for ethanol [9-12].

To a large extend, future ethanol trade may be driven by countries that are not necessarily interested in developing domestic biofuel production, but in reducing oil dependency and in meeting carbon emissions targets of the Kyoto protocol by substituting crude oil with biofuels (e.g. Sweden). Bioethanol can substitute petrol such as premium, super and lead replaced petrol [13].

\section{FEEDSTOCK PRODUCTION}

Ethanol can be produced from any biological feedstock that contains appreciable amounts of sugar or materials that can be converted into sugar such as starch or cellulose. As shown in Figure 1, many different feedstock sources can be used for ethanol production. They can be divided into sugary, starchy and cellulosic feedstock $[14,15]$.

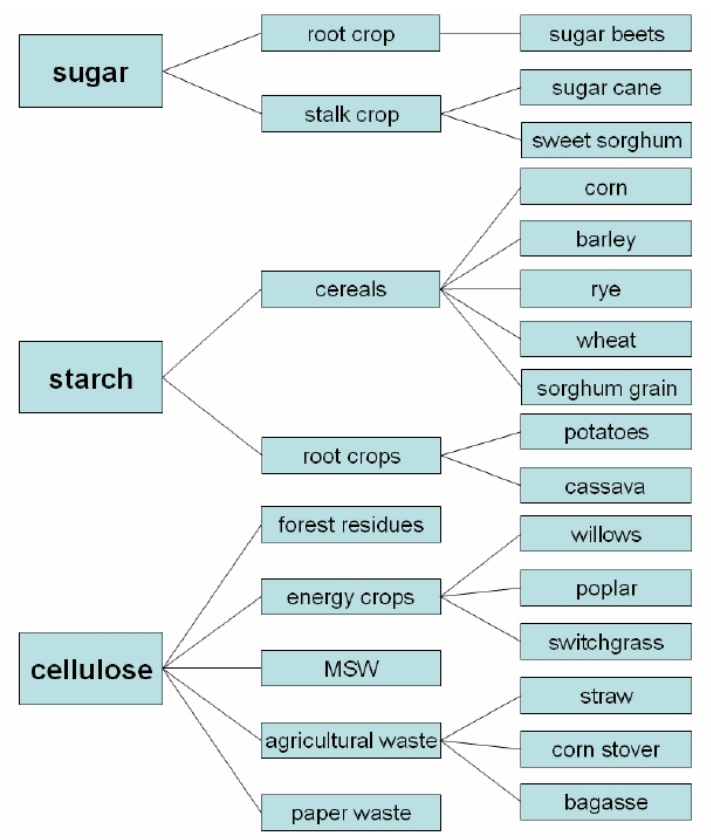

Figure 1 - Types of feedstock for ethanol production

Feedstock for ethanol production are sugar beets and sugar cane which contain high percentages of sugar. Sugars can be easily fermented. Brazil developed a successful fuel ethanol program from sugarcane. In Europe, sugar beets are used for ethanol production. Currently, ethanol imports from Brazil are entering the European fuel market.

Corn, wheat, barley, rye and other cereals are typical feedstock containing starch in their kernels. Starch can relatively easily be converted into sugar and then into ethanol. In the USA and Europe, ethanol is manufactured mainly from maize and grain. At the moment substantial capacities for the manufacture of ethanol are being created in Germany. Other starchy crops that can also be used for bioethanol production are sorghum grains, cassava and potatoes. Recent research includes bioethanol production from potatoes and waste potatoes from food industry $[2,4,7]$.

Since ethanol from sugar and starch bearing plants is readily available today, these feedstock types are also called first-generation feedstocks. First generation feedstock are characterized by the fact that only parts of the plants (starch, sugar, oil) are used for biofuel production.

Contrary to this, next-generation feedstock types provide the opportunity to use nearly the whole plant for biofuel production and not only parts of the plants (grains, tubes, stalks). In order to use second generation biofuels for ethanol production, advanced technologies are necessary. A large variety of feedstock is available for producing ethanol from biomass that contains large amounts of cellulose and hemicellulose. Cellulose and hemicellulose can be converted to sugar, though with more difficulty than conversion of starch.

Considered cellulosic biomass are agricultural wastes (including those resulting from conventional ethanol production), forest residues, municipal solid wastes (MSW), wastes from pulp/paper processes and energy crops. Cellulosic agricultural wastes for ethanol production include crop residues such as wheat straw, corn stover (leaves, stalks and cobs), rice straw and bagasse (sugar cane waste). Forestry wastes include logging residues as well as wood which is not used and thus left in the forest. MSW contains high percentages of cellulosic materials, such as paper and cardboard [3].

In contrast to cellulosic waste materials, dedicated energy crops, which are grown specifically for ethanol production, include fast-growing trees (poplars), shrubs (willows), and grasses (switchgrass). The cellulosic components of these materials range between $30 \%$ and $70 \%$ [16].

This new concept of utilizing cellulosic feedstock for bioethanol production is not yet applicable on the large scale, but is currently subject to intensive research. However, independent from the feedstock type, the large-scale production of agricultural ethanol requires substantial amounts of cultivable land with fertile soils and water (except for wastes). Therefore ethanol production is less attractive for densely occupied and industrialized regions like Western Europe, or for regions where desire for increased farmland puts pressure on important natural resources like rainforests.

\section{BIOETHANOL PRODUCTION}

Ethanol, also known as "ethyl alcohol" or "grade alcohol", is a flammable, colorless chemical compound, one of the alcohols that is most often found in alcoholic beverages.

Generally, ethanol can be produced either synthetically from petrochemical feedstock (petroleum) 
or by microbial fermentation which is applicable to bioethanol production. The process for production of fuel bioethanol from biomass can be broken down as follows:

- Feedstock production: harvesting, reception, storage

- Physical pretreatment: milling

- Saccarification: conversion of starch and cellulose into sugar

- Chemical treatment: dilution of the sugars with water and addition of yeast or other organisms
- Fermentation: production of ethanol in solution with water along with waste and by-products

- Distillation: separation of ethanol

- Dehydration: removal of the remaining water by molecular sieves

- Co-product preparation: Drying of the alcohol free stillage (mash) for high-value animal feed

These steps in the feedstock-to-ethanol conversion process largely depend on the type of feedstock. They are shown for different feedstock sources in Table $1[17,18]$.

Table 1 - Ethanol production steps by feedstock and conversion technique

\begin{tabular}{|c|c|c|c|c|c|c|}
\hline $\begin{array}{l}\text { Feedstock } \\
\text { type }\end{array}$ & Feedstock & $\begin{array}{l}\text { Harvest } \\
\text { technique }\end{array}$ & $\begin{array}{c}\text { Feedstock conversion } \\
\text { to sugar }\end{array}$ & $\begin{array}{c}\text { Process } \\
\text { heat }\end{array}$ & $\begin{array}{l}\text { Sugar conversion } \\
\text { to Alcohol }\end{array}$ & Co-products \\
\hline \multirow[t]{2}{*}{$\begin{array}{l}\text { Sugar } \\
\text { crops }\end{array}$} & cane & $\begin{array}{l}\text { Cane stalk cut, } \\
\text { mostly taken } \\
\text { from field }\end{array}$ & $\begin{array}{l}\text { Sugars extracted } \\
\text { through bagasse } \\
\text { crushing, soaking, } \\
\text { chemical treatment }\end{array}$ & $\begin{array}{l}\text { Primarily } \\
\text { from } \\
\text { crushed } \\
\text { cane } \\
\text { (bagasse) } \\
\end{array}$ & $\begin{array}{l}\text { Fermentation } \\
\text { and distillation } \\
\text { of alcohol }\end{array}$ & $\begin{array}{l}\text { Heat, } \\
\text { electricity, } \\
\text { molasses }\end{array}$ \\
\hline & sugar beet & $\begin{array}{l}\text { Beets harve- } \\
\text { sted, foliage left } \\
\text { on the field }\end{array}$ & Sugar extraction & $\begin{array}{l}\text { Typically } \\
\text { from } \\
\text { fossil fuel }\end{array}$ & $\begin{array}{l}\text { Fermentation } \\
\text { and distillation } \\
\text { of alcohol }\end{array}$ & $\begin{array}{l}\text { Animal feed, } \\
\text { fertilizer }\end{array}$ \\
\hline \multirow[t]{3}{*}{$\begin{array}{l}\text { Starch } \\
\text { crops }\end{array}$} & wheat & $\begin{array}{l}\text { Starchy parts of } \\
\text { Plants } \\
\text { harvested; } \\
\text { stalks mostly } \\
\text { left in the field }\end{array}$ & $\begin{array}{l}\text { Starch separation, } \\
\text { milling, conversion to } \\
\text { sugars via enzyme } \\
\text { application }\end{array}$ & $\begin{array}{l}\text { Typically } \\
\text { from } \\
\text { fossil fuel }\end{array}$ & $\begin{array}{l}\text { Fermentation } \\
\text { and distillation } \\
\text { of alcohol }\end{array}$ & $\begin{array}{l}\text { Animal feed } \\
\text { (e.g. distillers } \\
\text { dried grains) }\end{array}$ \\
\hline & corn & $\begin{array}{l}\text { Starchy parts of } \\
\text { plants } \\
\text { harvested; } \\
\text { stalks mostly } \\
\text { left in the field }\end{array}$ & $\begin{array}{l}\text { Starch separation, } \\
\text { milling, conversion to } \\
\text { sugars via enzyme } \\
\text { application }\end{array}$ & $\begin{array}{l}\text { Typically } \\
\text { from } \\
\text { fossil fuel }\end{array}$ & $\begin{array}{l}\text { Fermentation } \\
\text { and distillation } \\
\text { of alcohol }\end{array}$ & $\begin{array}{l}\text { Animal feed } \\
\text { (e.g. distillers } \\
\text { dried grains), } \\
\text { sweetener }\end{array}$ \\
\hline & potatoes & $\begin{array}{l}\text { Potatoes } \\
\text { harvested, } \\
\text { foliage left on } \\
\text { the field }\end{array}$ & $\begin{array}{l}\text { Washing, mashing, } \\
\text { cooking, starch } \\
\text { separation, } \\
\text { conversion to sugars } \\
\text { via enzyme } \\
\text { application }\end{array}$ & $\begin{array}{l}\text { Typically } \\
\text { from } \\
\text { fossil fuel }\end{array}$ & $\begin{array}{l}\text { Fermentation } \\
\text { and distillation } \\
\text { of alcohol }\end{array}$ & $\begin{array}{l}\text { Animal feed, } \\
\text { industrial use }\end{array}$ \\
\hline \multirow[t]{2}{*}{$\begin{array}{l}\text { Cellulosic } \\
\text { crops }\end{array}$} & trees & $\begin{array}{l}\text { Full plant } \\
\text { harvested } \\
\text { (above ground) }\end{array}$ & $\begin{array}{l}\text { Cellulose conversion } \\
\text { to sugar via } \\
\text { saccarification } \\
\text { (enzymatic hydrolysis) }\end{array}$ & $\begin{array}{l}\text { Lignin and } \\
\text { excess } \\
\text { cellulose }\end{array}$ & $\begin{array}{l}\text { Fermentation } \\
\text { and distillation } \\
\text { of alcohol }\end{array}$ & $\begin{array}{l}\text { Heat, elec- } \\
\text { tricity, animal } \\
\text { feed, } \\
\text { bioplastics, } \\
\text { etc. }\end{array}$ \\
\hline & grasses & $\begin{array}{l}\text { Grasses cut } \\
\text { with } \\
\text { regrowth }\end{array}$ & $\begin{array}{l}\text { Cellulose conversion } \\
\text { to sugar via } \\
\text { saccarification } \\
\text { (enzymatic hydrolysis) }\end{array}$ & $\begin{array}{l}\text { Lignin and } \\
\text { excess } \\
\text { cellulose }\end{array}$ & $\begin{array}{l}\text { Fermentation } \\
\text { and distillation } \\
\text { of alcohol }\end{array}$ & $\begin{array}{l}\text { Heat, } \\
\text { electricity, } \\
\text { animal feed, } \\
\text { bioplastics, } \\
\text { etc. }\end{array}$ \\
\hline $\begin{array}{l}\text { Waste } \\
\text { biomass }\end{array}$ & $\begin{array}{l}\text { Crop } \\
\text { residues, } \\
\text { forestry } \\
\text { waste, } \\
\text { municipal } \\
\text { waste, mill } \\
\text { waste }\end{array}$ & $\begin{array}{l}\text { Collected, } \\
\text { separated, } \\
\text { cleaned to } \\
\text { extract material } \\
\text { high in cellulose }\end{array}$ & $\begin{array}{l}\text { Cellulose conversion } \\
\text { to sugar via } \\
\text { saccarification } \\
\text { (enzymatic hydrolysis) }\end{array}$ & $\begin{array}{l}\text { Lignin and } \\
\text { excess } \\
\text { cellulose }\end{array}$ & $\begin{array}{l}\text { Fermentation } \\
\text { and distillation } \\
\text { of alcohol }\end{array}$ & $\begin{array}{l}\text { Heat, } \\
\text { electricity, } \\
\text { animal feed, } \\
\text { bioplastics, } \\
\text { etc. }\end{array}$ \\
\hline
\end{tabular}

Ethanol produced by fermentation results in a solution of ethanol in water. For ethanol to be used as fuel, water must be removed. The oldest method therefore is distillation, but the purity is limited to
95-96 \% due to the formation of a low-boiling water-ethanol azeotrope. An azeotrope is a liquid mixture of two or more substances that retains the same composition in the vapor state as in the liquid 
state when distilled or partially evaporated under a certain pressure. It means that the composition of this liquid at its azeotropic composition can not be changed by simple boiling [19-20].

Thus it is not possible to obtain ethanol of higher purity of $96 \%$ by distilling any more dilute solution. But for blending with gasoline, ethanol purities of 99.5 to $99.9 \%$ are required, depending on temperature, to avoid separation. Currently, the most widely used purification method is a physical absorption process using molecular sieves.

\section{PROPERTIES OF BIOETHANOL}

The properties bioethanol is shown in table 2 and compared to the properties of fossil petrol.

Ethanol has many favorable properties. For example the octane number of ethanol is higher than the octane number of conventional petrol. The octane number influences the antiknocking property of the fuel.

A high octane number stands for an antiknocking fuel. Knocking describes uncontrolled combustion which puts heavy mechanical and thermal loads on the engine.

On the other hand, the energy yield of ethanol is about one third lower than petrol. One liter of ethanol substitutes only about 0.65 liters of petrol. This is due to the different caloric values of petrol and ethanol. The energy content of petrol is 32.45 $\mathrm{MJ} / \mathrm{l}$ and 21.17 $\mathrm{MJ} / \mathrm{l}$ of ethanol.

Another property of ethanol is its low vapor pressure. When stored as a pure fuel (or even as an E-85 blend), it has a lower vapor pressure than gasoline, and thus will have fewer evaporative emissions. In colder climates, the low vapor pressure of pure ethanol can cause cold start problems. Therefore in cold climates ethanol is blended with gasoline (E85). In contrast, lowerlevel blends of ethanol in gasoline, tend to raise the vapor pressure of the base gasoline to which ethanol is added. When ethanol is blended up to about 40 percent with gasoline, the two fuels combined have higher evaporative emissions than either does on its own $[4,20]$.

Table 2 - Parameters of bioethanol in comparison with petrol

\begin{tabular}{|c|c|c|c|c|c|c|c|}
\hline & $\begin{array}{l}\text { Density } \\
{\left[\mathrm{kg} / \mathrm{dm}^{3}\right]}\end{array}$ & $\begin{array}{l}\text { Viscosity } \\
{\left[\mathrm{mm}^{2} / \mathrm{s}\right]}\end{array}$ & $\begin{array}{c}\text { Flashpoint } \\
{\left[{ }^{\circ} \mathrm{C}\right]}\end{array}$ & $\begin{array}{c}\text { Caloric } \\
\text { value [at } \\
20^{\circ} \mathrm{C} \\
\mathrm{MJ} / \mathrm{kg} \text { ] }\end{array}$ & $\begin{array}{c}\text { Caloric } \\
\text { value } \\
{[\mathrm{MJ} / \mathrm{I}]}\end{array}$ & $\begin{array}{c}\text { Octane } \\
\text { number } \\
\text { [RON] }\end{array}$ & $\begin{array}{c}\text { Fuel } \\
\text { equivalence } \\
{[\mathrm{l}]}\end{array}$ \\
\hline Petrol & 0.76 & 0.6 & $<21$ & 42.7 & 32.45 & 92 & 1 \\
\hline Bioethanol & 0.79 & 1.5 & $<21$ & 26.8 & 21.17 & $>100$ & 0.65 \\
\hline
\end{tabular}

Different blends of ethanol and petrol have different properties. Depending on the situation and the desired fuel, ethanol is therefore blended with gasoline at any ratio. Common ethanol blends are E5, E10, E20, E25, E70, E85, E95, and E100, which contain $5 \%, 10 \%, 20 \%, 25 \%, 70 \%, 85 \%$, $95 \%$, and $100 \%$ ethanol, respectively. Also other varying quantities are possible. In the European Union, so-called flexible-fuel vehicles (FFV) are currently entering the market. They can run with an ethanol proportion of any mixture up to $85 \%$.

Ethanol is also increasingly used as an oxygenate additive for standard petrol, as a replacement for methyl tertiary butyl ether (MTBE). MTBE is usually mixed with petrol as an additive to improve the octane number. Because MTBE has toxic properties and is responsible for considerable groundwater and soil contamination, MTBE is more and more frequently replaced by ETBE (ethyl tertiary butyl ether). ETBE is produced from bioethanol and may be mixed in maximum quantities of 15 percent with petrol [21].

\section{BIOETHANOL EMISSIONS}

One of the major drivers of biofuel promotion worldwide is the concern about climate change and the potential of biofuels to reduce greenhouse gas emissions (GHG emissions). However, the GHG balance for bioethanol is highly variable and includes emissions of cultivation, transport, conversion process and distribution. Further, the GHG reduction potential depends on type of feedstock, agricultural practices, site productivity, conversion technology [22].

Generally, ethanol produced from sugar cane grown in Brazil shows one of the greatest benefits. This is confirmed by several studies which all have found that emission reductions of sugar cane ethanol in Brazil far exceed those from grain-based ethanol produced in Europe and the United States. Estimate that the total life-cycle GHG emissions reductions associated with the ethanol industry in Brazil are equivalent to 46.6 million tons annually [22]. These are approximately $20 \%$ of Brazil's annual fossil fuel emissions. This is due to high site productivity in Brazil and its favorable climate for sugar cane, which is highly productive and only needs low inputs of fertilizer. Additionally almost all conversion plants use bagasse for process energy which also reduces $\mathrm{GHG}$ emissions. Many plants also co-generate heat and electricity. Well-towheel $\mathrm{CO}_{2}$ emissions of sugar cane-ethanol are estimated to be, on average $0.20 \mathrm{~kg}$ per liter of fuel used, versus $2.82 \mathrm{~kg}$ for gasoline. These figures based on $\mathrm{CO}_{2}$ also take methane and $\mathrm{N}_{2} \mathrm{O}$ emissions into account (both mainly released from 
farming, from the use of fertilizers and from $\mathrm{N}_{2}$ fixed in the soil by sugar cane then released to the atmosphere) [20].

Apart from sugarcane, other combinations of biofuel feedstock and conversion processes can reduce well-to-wheels $\mathrm{CO}_{2}$-equivalent $\mathrm{GHG}$ emissions to near zero, too. An example therefore is enzymatic hydrolysis of cellulose where ethanol is produced and biomass is used as process fuel.

In contrast, ethanol from corn shows very small GHG reductions within all potential feedstock options. Using commercial processes, the use of ethanol derived from grains, brings a $20 \%$ to $40 \%$ reduction in well-to-wheels $\mathrm{CO}_{2}$-equivalent $\mathrm{GHG}$ emissions, compared to gasoline.

For Europe, ethanol production from sugar beets is important, due to its high dominance in several European countries. Some European studies show that this feedstock and conversion process can provide up to a $56 \%$ reduction in well-towheels GHG emissions, when compared to gasoline.

Nevertheless, some results point out that using ethanol to make ETBE results in even greater GHG savings than blending ethanol directly with gasoline. This is because ETBE replaces MTBE, which has relatively high energy demand, whereas ethanol replaces gasoline, which requires less energy for production than does MTBE.

Among the biggest benefits from using ethanol is the high reduction potential of carbon monoxide (CO) emissions. The use of E10 is reported to achieve a $25 \%$ or greater reduction in carbon monoxide emissions due to the increased oxygen content of ethanol. Ethanol contains approximately $35 \%$ oxygen which promotes a more complete combustion of the fuel. Thus, in some countries, ethanol is used as oxygenate for fossil petrol and is increasingly replacing the oxygenate MTBE due to the high ground water contamination potential of MTBE [21].

On the other hand ethanol-blended petrol emits higher evaporative hydrocarbons $(\mathrm{HC})$ and other volatile organic compounds (VOCs) than petrol. Generally, adding the first few per cent of ethanol triggers the biggest increase in volatility. Raising the ethanol concentration further does not lead to significant further increases (and in fact leads to slight decreases), so that blends of $2 \%, 5 \%, 10 \%$ and more have a similar impact.

Impacts of ethanol on nitrogen oxides (NOx) are generally minor, and can either be increased or decreased, depending on conditions. NOx emission from combustion of ethanol blends range from a $10 \%$ decrease to a $5 \%$ increase over emissions from gasoline. However, if the full life cycle of ethanol is considered, NOx emissions can be significantly higher mainly due to emissions from feedstock production. NOx is released from fertilizers used to grow bioenergy crops, and is emitted mostly outside urban areas.

When gasoline is blended with ethanol, emissions of most toxic air pollutants decrease. This is primarily due to the dilution effect of ethanol which substitutes some part of gasoline, which emits toxic air pollutants. For instance, toxic emissions of benzene, 1,3-butadiene, toluene and xylene decrease when ethanol is added. Benzene is a carcinogen, while olefins and some aromatics which are emitted by the combustion of fossil fuels as well, are precursors to ground-level ozone. While few studies have looked at the impacts on pollution levels from high blends, it appears that impacts are similar to those from low blends.

The above mentioned toxics benzene, 1,3butadiene, toluene and xylene, which are emitted by the combustion of fossil fuels, are considered to be more dangerous than emissions of ethanol combustion. During ethanol fuel combustion, emissions of the toxic air pollutants acetaldehyde, formaldehyde, and peroxyacetyl nitrate (PAN) increase relative to straight gasoline. Acetaldehyde is emitted most, but it is a less-reactive and lesstoxic pollutant than formaldehyde. PAN is an eye irritant and is harmful to plants. No one of these pollutants is present in the unburned fuel, as they are only created as byproducts of incomplete combustion. Nevertheless, impacts of acetaldehyde and PAN seem to be minor as emissions are relatively low compared to other sources and as they can be efficiently removed by a vehicle's catalytic converter [20-23].

\section{CONCLUSION}

The development of new technologies for processing and using bioethanol is steadily progressing. Bioethanol is becoming more and more competitive compared to fossil fuels. The use of all biofuels features a number of advantages suitable for achieving energy, environmental, agricultural and trade policies. As a result, bioethanol is emerging as a popular step towards a more sustainable transportation sector, and several European countries have introduced advanced policies to support the production and use of bioethanol.

Generally bioethanol has the potential to generate many positive externalities, such as reduced greenhouse gas emissions, decreased air pollution, and job creation. Additionally biofuels decrease dependency from crude oil imports. Consequently biofuels are a more socially and environmentally desirable liquid fuel.

Worldwide bioethanol plays the most important role as an alternative fuel which is mainly produced in Brazil (59 \%) and the USA (36 \%).

In future bioethanol is becoming even more advantageous to fossil fuel mainly due to improvements of feedstock production and conversion processes. 


\section{REFERENCES}

[1] D. Pimentel (2003) Ethanol fuels, Energy balance, economics and environmental impacts are negative, Nat. Resour., 12, 127-134.

[2] L.Mojović, D.Pejin, O.Grujić, S.Markov, J.Pejin, M.Rakin, M.Vukašinović, S.Nikolić, D.Savić (2009) Progress in the production of bioethanol on starchbased feedstocks, Chem. Ind. Chem. Eng. Q., 15, 221-226.

[3] J.S.Kim, B.G Kim, C.H.Lee, S.W.Kim, J.H.Koh, A.G.Fan (1997) Development of clean technology in alcohol fermentation industry, J. Clean. Prod. 5, 263-267.

[4] S.Kim, B.E.Dale (2005) Environmental aspects of ethanol derived from no-tilled corn grain: nonrenewable energy consumption and greenhouse gas emissions, Biomass Bioenergy 28 , 475-489.

[5] M.R.Ladisch, K.Dyck (2005) Dehydration of ethanol - new approach gives positive energy balance, Science 205, 898-900.

[6] A.Mc.Allon, F.Taylor, W.Yee, K.Ibsen, R.Wooley (2000) Determining the cost of producing ethanol from corn starch and lignocellulosic feedstocks, National Renewable Energy Laboratory, Colorado, USA.

[7] F.Taheripour, T.W.Hertel, W.E.Tyner, J.F Beckman, D.K.Birur (2008) Biofuels and their byproducts- Global economic and environmental implications, American Agricultural Economics Association Meeting, Orlando, FL, pp.43 - 51.

[8] W.E.Tyner (2007) Policy alternatives for the future biofuels industry, J. Agr. Food Ind. Organ., 5 (2) 27 $-33$.

[9] P.Moriarty, D.Honnery (2012) What is the global potential for renewable energy, Renew Sustain Energ Rev, 16, 244 - 252

[10] M.Hook, X.Tang (2013) Depletion of fossil fuels and anthropogenic climate change, Energy Policy, 52, $797-809$

[11] P.S.Nigam, A.Singh (2012) Production of liquid biofuels from renewable resources, Prog. Energy Combust 37, $52-68$

[12] M.Balat (2011) Production of bioethanol from lignocellulosic materials via the biochemical path way, Energy Converts Manage 52, 858 - 875.
[13] G.M.Bohimann (2006) Process economic considerations for production of ethanol from biomass feedstocks, Ind. Biotechnol. 2, $14-20$.

[14] D.Ivetić, M.Antonov (2013) Environmental management through fossil fuels replacementglobal and local potential of agricultural waste for bioethanol production, Becici, Montenegro, pp.191 $-196$.

[15] S.T.Merino, J.Cherry (2007) Progress and Challenges in Enzyme Development for Biomass Utilization, Adv. Biochem Engin/Biotechnol, 108, $95-120$

[16] C.Bessou, F.Ferchaud, B.Gabriele, M.Bruno (2009) Biofuels, greenhouse gases and climate change, Agron Sustain Dev, 31, 1 - 79.

[17] S.R.Armstrong (2008) Ethanol Brief Report on its Use in Gasoline, http://www. ethanol. org/ pdfs/health_impacts.pdf

[18] P.C.Badger (2002) Ethanol from cellulose general review. ASHS Press, Alexandria, Greece

[19] R.Igelspacher (2003) Ganzheitliche System analyse zur Erzeugung und Anwendung von Bioethanol im Verkehrssektor - Energie und Anwendungstechnik, Insttitut für Energeie technik TU München.

[20] F.J.Kaltner, G.F.D.Azevedo, I.A.Campos, A.O.F.Mundim (2004) Liquid Biofuels for Transportation in Brazil, Potential and Implications for Sustainable Agriculture and Energy in the 21st century, http://www. fbds.org.br/IMG/pdf/doc116.pdf

[21] I.C.Macedo, M.R.L.V.Leal, J.E.A. R.Dasilva (2006) Greenhouse Gas (GHG) Emissions in the Production and Use of Ethanol in Brazil - Present Situation, Prepared for the Secretariat of the State of São Paulo; http://www.senternovem. nl/ mmfiles/ 135550_tcm24-124345.pdf

[22] N.Paul, D.Kemnitz (2006) Biofuels - Plants, Raw Materials, Products. - Fachagentur Nachwachsende Rohstoffe e.V. (FNR), WPR Communication, Berlin

[23] G.Ulrich (1999) The Fate and Transport of EthanolBlended Gasoline in the Environment, Goveneur's Ethanol Coalition Lincoln, Nebrasca

\section{IZVOD}

\section{BIOETANOL KAO GORIVO ZA MOTORE SA UNUTRAŠNJIM SAGOREVANJEM}

Biogoriva za koje se smatra da će biti najperspektivnija u skorijoj budućnosti su bioetanol, biodizel, čisto biljno ulje i biometan. Mnoga biogoriva generišu velike benefite u poređenju sa fosilnim gorivom. Korišćenje bioetanola uglavnom će zavisiti od količine obnovljive biomase kao raspoložive sirovine. Sagorevanjem bioetanola dobijenog iz obnovljivih sirovina dolazi do znatne redukcije gasova koji izazivaju tzv. efekat staklene bašte u poređenju sa sagorevanjem fosilnih goriva. Hemijske $i$ fizičke osobine bioetanola su bliske sa fosilnim gorivima usled čega on može biti korišćen da zameni benzin u postojećim motorima. Zbog njegove preferirane proizvodnje i potrošnje očekuje se njegov veliki društveno ekonomski uticaj naročito na lokalnom nivou. Proizvodnja bioetanola otvara nove tržišne mogućnosti za korišćenje poljoprivrednih produkata i nove šanse za poljoprivredne proizvođače. $U$ budućnosti poljoprivreda neće igrati ulogu samo u proizvodnji hrane već takođe i u obezbeđenju energije.

Ključne riječi: biogorivo, bioetanol, obnovljivi energetski resursi, biomasa, fosilna goriva.

Naučni rad

Rad primljen: 18.03.2015.

Rad prihvaćen: 7.05.2015.

Rad je dostupan na sajtu: www.idk.org.rs/casopis 